\title{
Language Teaching and Dictionary Use: An Overview
}

\author{
Adelia Carstens, University of Pretoria, \\ Pretoria, South Africa
}

\begin{abstract}
The main objective of language teaching is to improve language proficiency with regard to reading writing, speaking and listening. The dictionary is one of the aids that can be used to attain this goal. There are however a number of stumbling blocks in the way of optimal utilization of dictionaries. Poor reference skills and a lack of knowledge with regard to dictionary typology seem to be the most prominent among these. It is argued that reference skills could be developed by the teaching of reference strategies, preferably by integrating dictionary-using exercises with other language learning activities, and by structuring these exercises according to the stages of the actual reference process. Dictionary pedagogy should ideally be introduced in the L1 class during primary education, but students will definitely still benefit if dictionary skills are taught during the intermediary stages of second or foreign language learning. It is anticipated that students who have become convinced of the problem-solving potential dictionaries through personal experience will become independent learners who will continue using dictionaries even after the years of formal education.
\end{abstract}

Keywords: DICTIONARY PEDAGOGY, DICTIONARY-USING SKILLS, LANGUAGE PROFICIENCY, LANGUAGE TEACHING, REFERENCE SKILLS

Opsomming: Taalonderrig en woordeboekgebruik: 'n oorsig. Die hoofoogmerk in taalonderrig is om die taalvaardigheid van leerlinge te verbeter met betrekking tot lees, skryf, praat en luister. Die woordeboek is maar een van die hulpmiddels wat gebruik kan word om hierdie doel te bereik. Daar is egter ' $n$ aantal struikelblokke wat in die weg lê van die optimale benutting van woordeboeke. Swak naslaanvaardighede en gebrekkige kennis aangaande woordeboektipologie blyk die belangrikste probleme te wees. Daar word van die standpunt uitgegaan dat woordeboekgebruiksvaardighede wel verbeter kan word deur die onderrig van naslaanstrategieë, verkieslik deur woordeboekgebruiksoefeninge met ander leeraktiwiteite te integreer, en deur die oefeninge te struktureer op basis van die verloop van die naslaanproses. Die ideaal is dat daar met woordeboekpedagogiek in die moedertaalklas gedurende die primêre onderwysfase begin word. Leerlinge en studente sal egter beslis ook daarby baar as woordeboekvaardighede gedurende die intermediêre fases van tweede en vreemdetaalonderrig onderrig word. Die verwagting word gestel dat leerlinge wat proefondervindelik oortuig geraak het van woordeboeke se probleemoplossende potensiaal, selfstandige leerders sal word wat sal anhou om woordeboeke te gebruik selfs nadat die tydperk van formele taalonderrig afgesluit is.

Sleutelwoorde: WOORDEBOEKPEDAGOGIEK, VAARDIGHEDE IN WOORDEBOEKGEBRUIK, TAALVA ARDIGHEID, TAALONDERRIG, NASLAANVAARDIGHEDE 


\section{Introduction}

The main objective of language teaching is to improve language proficiency with regard to speaking, listening, reading and writing. A variety of tools can be employed as facilitators, for instance textbooks, grammar exercises, games, role play, translations, voice recordings, video tapes, creative writing, and dictionaries. Dictionary use must however not be seen as an end in itself. The dictionary is but one of the aids available to the language teacher to help students help themselves (cf. Hartmann 1987: 181, Bejoint 1989: 209).

The extent to which dictionaries do (or could) contribute towards language acquisition and the improvement of language proficiency has not been researched conclusively. The only real evidence that we have, is that students who know their dictionaries well, perform better in language tasks than those who do not. The main problem in this regard is that reference skills do not develop naturally, but must be learnt. Furthermore, students do not exhibit a natural affinity to dictionaries. The bright side of the picture is, however, that dictionary-using skills can be learnt and improved by principled teaching of reference strategies. (cf. Béjoint 1989: 212).

This overview firstly intends to provide reasons why lay persons (including students) are reluctant to use dictionaries. It secondly intends to demonstrate that these reasons can essentially be reduced to lack of knowledge with regard to dictionary typology (appropriateness of the dictionary type) and to poor dictionary-using skills. The suggestion which is offered, is that reference skills must be taught by integrating dictionary-using exercises with other language learning activities. Dictionary-teaching should however be structured according to the stages of the actual reference process. Along this way skillful (but not uncontrolled!) dictionary use can indeed facilitate more independent language learning.

\section{Why are dictionaries under-utilized?}

Even where dictionaries are available, they are often not utilized to the full and are frequently regarded as a last resort when the student "can't work out" what a word means (cf. Scholfield 1982: 185). A number of factors may contribute towards this situation.

\subsection{Language syllabuses}

In South Africa, as in many European countries (see Blok 1994: 279 and Olijkan $1994^{\mathrm{I}}: 280$ with regard to the situation in the Netherlands), school syllabuses merely state that pupils have to be able to use general sources of reference. In other words no direct mention is made of dictionary use or dictionary-using 
skills. It is therefore not surprising that textbooks do not offer any information or exercises on dictionary use nor any strategies for integrating dictionary use with language learning activities. This unfortunate situation causes many teachers to regard dictionary use as peripheral to language learning and the language-teaching programme.

\subsection{Availability of dictionaries}

Due to a system of education which has for more than four decades offered little support to the majority of South African school pupils, dictionaries (even the pocket-size editions) have become a luxury in many language classrooms. Next to largely inadequate textbooks the teacher is usually the only source of linguistic information. This untenable situation is partially responsible for totally inadequately equipped second and foreign language speakers in the South African work force.

\subsection{Aversion to dictionary use}

Resistance to dictionary use is a world-wide tendency, especially among school pupils (cf. Houtman and Wouters 1994: 307). It is probably due to the fact that most students lack adequate reference skills and that dictionaries have resultantly frustrated them or let them down.

\subsection{Communicative interference}

According to Beattie (1973: 161) looking up a word in a dictionary during decoding activities such as reading, may cause the reader to regard an L2 or a foreign language text as a mere sequence of words: when an unknown word occurs the reader switches off, looks up the word, and switches on again. Constant interruptions also take away much of the pleasure of reading. The reader may argue that one or two unknown words in a paragraph do not render it unintelligible and that interrupting the activity to use a dictionary is not worth while. Furthermore, the context often provides clues to the meaning of an unknown word.

Frequent dictionary use may also affect production activities adversely by deferring the student's attention from the logical whole to individual lexical problems. Kipfer (1987: 48) rightfully concludes that "Few students can continually sustain an attention span to bridge such interruptions in reading and writing". 


\subsection{Knowledge of dictionary types}

Kipfer (1984: 1) states the fact that "dictionaries are prepared to meet users' different needs", and then asks the rhetorical question: "how can the user find the dictionary(ies) meant for him?"

According to Béjoint (1989: 208) many users are completely unaware of the variety of dictionaries commercially available, and of the differences between them. This fact was verified by a survey among American senior secondary students conducted by Kipfer (1987: 46). Results showed that few of them could explain the difference between the basic dictionary types, which (with reference to language learning) would be the bilingual dictionary, the monolingual learners' dictionary, and different sizes of the standard monolingual dictionary. Using a less appropriate dictionary type must necessarily lead to frustration and reluctance to use dictionaries at all.

Even teachers are often unaware of the advantages and disadvantages different dictionary types have with regard to different stages of learning (introductory, intermediate and advanced) and different learning tasks (for instance encoding and decoding). Many teachers therefore content themselves with the outdated and / or inappropriate dictionaries left by their predecessors.

\subsection{Students' poor reference skills}

Reluctance towards dictionary consultation may be due to the fact that students lack the necessary skills to find answers to their own language problems, partly because they have not received any dictionary training. If pupils do attempt to use a dictionary they do not make full use of what is offered. According to Kipfer (1987: 45) most students who have not received any dictionary training, use the dictionary solely as a guide to spelling and meaning. Important usage information contained in grammatical codes, labels, collocations and example sentences is seldom utilized.

Kipfer (1987: 50) is convinced that not enough is being done at school level to promote dictionary literacy. Her conclusion is supported by a survey done with 292 senior secondary school pupils of whom $52 \%$ indicated that they did not know their dictionaries well, and that they had never read or been taught anything about dictionaries, the lexicographical process or the differences between dictionary types (Kipfer 1987: 45-46).

It must be remembered that even learners' dictionaries are not necessarily fully transparent. According to Herbst and Stein (1987: 115) dictionary use requires a specific competence because of the wide spectrum of information contained, and most untrained users lack this competence. As every other reference system, dictionaries require certain reference skills which "need to be learnt and mastered by repeated and constant exercise. Otherwise they will not be remembered and will have to be reactivated or relearnt" (Herbst and Stein 1987: 116). 
General agreement on the methodology of dictionary pedagogy has not been achieved yet. Authors such as Herbst and Stein (1987: 116) advocate the direct teaching of dictionary skills in language classes at school and university, while other scholars suggest that dictionary exercises must be integrated with different kinds of other language learning activities such as comprehension, composition, oral work, grammar, vocabulary expansion, etc. Although this is a pivotal matter it will not be further discussed in this paper.

\subsection{The teacher's approach, knowledge, and attitude}

According to Béjoint (1989: 208) a number of studies indicate that most teachers are rather apathetic towards dictionaries and dictionary use. This reluctance to promote dictionary use may arise from the teacher's inadequate personal knowledge of dictionaries and his / her poor reference skills. A preliminary survey among secondary school teachers in Pretoria indicated that many of them have only a blurred picture of dictionary structure: some cannot even tell the difference between a definition and a usage example.

A second factor causing teachers' reluctance to promote dictionary use may be their strong adherence to the communicative approach. Communication-centered teaching could be stretched to such lengths that dictionary use is rendered unnecessary or superfluous. "For", it could be asked, "should the focus of language teaching not be on the communication process and the student's ability to convey his / her intention to the hearer(s), and nót on the microstructural elements of the language code"?

Olijkan and Wouters (1994: 252) do however not view dictionary use as contradictory to recent lexical acquisition theories. Pupils can still be encouraged to deduce or guess the meaning of a word from the surrounding context and then check their hypotheses by looking up the problematic item in a dictionary.

A rigid grammatical approach can be as harmful (cf. Stein 1990: 401) if vocabulary acquisition is delayed until the rudiments of pronunciation and a substantial proportion of the grammatical system have been mastered. This approach did much harm to previous generations of students by providing them with vocabulary lists, but not making them competent in extracting guidance from reference books such as dictionaries.

Béjoint (1989: 209) summarizes the task of the language teacher and language lecturer as follows:

"The true objective, therefore, is to help the students help themselves, to help them to 'learn for themselves from dictionaries' ... to help them become independent of a teacher ... and this is very important in a world that stresses individual learning". 


\section{Dictionary pedagogy}

\subsection{General aspects}

Despite the pitfalls, negative attitudes and probable frustrations connected with dictionary use the dictionary has an important place in language edu. cation. According to Herbst and Stein (1987) dictionary-using skills have a general, interdisciplinary application: these skills contribute towards the acquisition of general reference skills and the development of discriminating skills; they facilitate achievement control and serve as guides to self-study and self-education. Beattie (1973: 161-162) argues that the learner who has not only learnt a language, but has learnt how to learn will be less dependent on his / her teachers. He does however foresee a pedagogical problem if the student who has become more independent of the teacher by using dictionaries, simply transfers his / her dependence to the dictionary.

\subsection{Specific skills}

Appropriate use of alphabetic dictionaries firstly presupposes that the user will be acquainted with the basic structural organization of dictionaries (at macro as well as at micro level). Making maximal use of the information offered in dictionaries secondly presupposes some knowledge of the usage values of different dictionary types. Knowledge about dictionary typology is especially important for the teacher or lecturer who has to be adequately equipped for channeling students' needs and questions appropriately and for making informed recommendations with regard to the purchase of dictionaries for specific target groups.

This overview will however only deal with dictionary-using skills based on knowledge of the structural organization of dictionaries, and not with the role of dictionary typology in language teaching. The basic claim which is put forward and defended is that looking-up requires the application of certain skills in a systematic way (Scholfield 1982: 185).

\subsubsection{Dictionary structure and reference procedures}

Blok (1994: 278) remarks that dictionary use is not such an ordinary skill as is often assumed. Dictionary-using skills must be learnt - be it by means of dictionary workbooks such as those compiled by Whitcut (1979), Underhill (1980) and Lewis and Pugmire (1980), or by means of regular exercises integrated with other learning tasks.

The following diagram, presented by Hartmann (1989: 105) as an adaptation of Scholfield (1982: $186 \mathrm{ff}$.), specifies the most important moments in the 
reference process and could be used to structure the teaching of dictionaryusing skills:

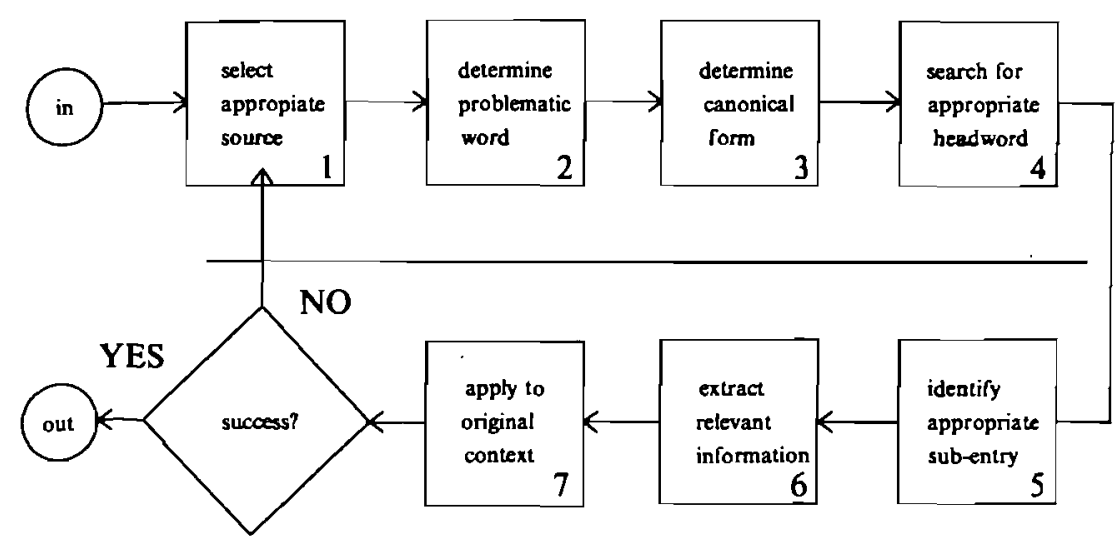

According to this diagram it is firstly important that students should be informed of the diversity of sources that can be used (e.g., a bilingual dictionary, a monolingual learners' dictionary, a standard monolingual dictionary, a dictionary of synonyms, etc.). When an appropriate source has been decided upon, the word in question must be reduced to its canonical or original form in order to find it in the dictionary. This action firstly presupposes that the student knows the alphabetical ordering principle of the dictionary and is acquainted with the use of key words at the top of the pages. It also presupposes basic knowledge of the grammatical structure of the language. When the headword has been identified the user can move on to the appropriate microstructural entry from which the required information must be extracted, for instance a specific sense with its accompanying example sentences and collocations. After the information has been interpreted by the user, he / she can return to the original text and map the dictionary entry onto it. The user should now be able to decide whether the particular entry fits the original context or whether the procedure (or part of it) should be repeated.

The following checklist, adapted from Béjoint (1989: 210-211), elaborates on Hartmann's strategic model, specifically with regard to step 6 (extract the relevant information). D below explicates the types of microstructural information the user should be able to extract after sufficient exercise:
A. Find an appropriate reference work
B. Determine the problematic lexical item
C. Find the lexical item in the dictionary
(c 1) Know the principles of alphabetical ordering
(c 2) Understand the principles of lemmatization in the particular language / dictionary 
(c 3) Reduce the word in question to its canonical form (e.g., in the case of a plural, participle, past tense form, particle verb, etc.)

(c 4) Guess how the word (in its canonical form) is spelled if you do not know

(c 5) Find the appropriate headword, focusing on the key words at the top of each page

(c 6) Find the particular lexical item, even if it forms part of the information given about a related headword, for instance if it is a derived word or an idiom

(c 7) Choose between homonyms by briefly looking at other information types, such as a usage label, a part of speech marker, a grammatical code, the definition, etc.

(c 8) Use more than one list (for instance the list of abbreviations, list of proper names, etc.) if you cannot locate the item in the main body of the dictionary.

\section{Find specific microstructural information}

(d 1) Find information concerning pronunciation, syllable stress and division of syllables

(d2) Find information concerning different forms of the lexical item, for instance plural, diminutive, degrees of comparison, conjugation of the verb, alternate spellings, etc.

(d 3) Find grammatical information with regard to the lexical item, e.g., part of speech, verb pattern, choice of preposition, etc. (To accomplish this you need to know the codes used by the particular dictionary or where these may be found in the dictionary.)

(d 4) Find usage information concerning the lexical item. (This step presupposes knowledge of labels, their abbreviations and their scope)

(d 5) Find the appropriate sense of a polysemic word

(d 6) Find information on related words, for instance synonyms, antonyms, the superordinate (genus), co-hyponyms, etc.

(d 7) Find information on the history of the word, e.g., language of origin and etymology (related forms in previous stages of the language as well as cognates in other languages)

(d 8) Find an appropriate translation equivalent in a bilingual dictionary

(d 9) Find an appropriate context for the use of the lexical item (in other words make sure that you use the word in accepted collocations) or compare the word in the onginal context with the context given in the dictionary.

Students must however be brought to realize that a dictionary only forms part of a problem-solving package (Hannay 1994: 254). Even an unabridged dictionary can never be more than a collection of guidelines for understanding and producing words and expressions. In most cases students must use their own internalized linguistic knowledge for interpreting dictionary entries. 


\subsubsection{How and when must reference skills be taught?}

As mentioned above, current South African school syllabuses neither explicitly provide for dictionary lessons nor do they promote the integration of dictionary-using with other learning activities. It is the teacher who must decide how and when dictionaries should be introduced. Béjoint (1989: 211) suggests that dictionary training must take place in two phases: Firstly the aim should be to help students to find answers on questions arising during formal learning activities. This phase may be termed the phase of "controlled use". The second goal should be to help pupils find answers on their own questions ("free use"), e.g., during reading and creative writing.

Although they provide some insight, these suggestions do not shed light on the methodology that should be followed. Must the dictionary be introduced by formal lessons on dictionary-use, or should practising of dictionaryusing skills be subtly integrated with other learning activities? If the first option is chosen it may further be asked whether the course should be presented at the hand of a language structure oriented workbook such as Janet Whitcut's Working with LDOCE (1979), Adrian Underhill's Use Your Dictionary 1 , or whether it should be presented at the hand of a look-up strategy model such as Hartmann's outlined above. The mentioned workbooks do contain useful exercises (Scholfield 1982: 193) but have the following disadvantages:

- they are largely based on one or more monolingual dictionaries published by (variously) Longman and Oxford;

- they are structured according to grammatical criteria (orthographic, phonetic, morphological, syntactic, semantic, pragmatic) rather than according to a step-by-step look-up strategy;

- they concentrate on receptive activities;

- they give no attention to bilingual dictionaries.

Lewis and Pugmire's How to use your Dictionary (1980) perhaps comes a step closer to integrating a structural, strategic and specific needs approach, but still focuses too strongly on decoding and also gives too little information on the bilingual dictionary.

To the question When should dictionaries be introduced? there is no simple answer. We can merely project that the ideal dictionary user will be that user who has been taught basic dictionary conventions and reference skills with regard to the L1 monolingual dictionary during primary education (Lombard 1994: 206; Béjoint and Moulin 1987: 114).

Experience has however taught that dictionaries usually only become part of the teaching equipment when formal teaching of L2 or a foreign language is

Barbara Ann Kipfer's Workbook on Lexicography is not considered a worktook for dictionaryusers, but as a workbook for aspiring lexicographers and lexicography students. 
introduced. This is partially due to the fact that there has not, until recently, existed any monolingual dictionaries for the African languages. Some scholars warn against early introduction of dictionaries in the L2 or foreign language class. According to Snell-Hornby (1987: 160) the first stage of learning a new language must focus on texts and typical situations, and vocabulary should only be learnt in context. When the student has sufficiently mastered the system of the new language to compare it to the L1 the bilingual dictionary or the monolingual learners' dictionary should be introduced.

The teacher must however guard against uncontrolled dictionary use (cf. Olijkan 1994: 2892; Béjoint 1989: 209) as this may lead to word-for-word translation, which is "probably one of the worst ways of using a dictionary" (Béjoint and Moulin 1987: 106). Frequent dictionary use during reception activities may cause the reader or listener to lose the connection of the word with the context (Bogaards 1994: 269). Interruption of production activities may inhibit creative thought or may shift the focus from the narrative structure to the structure of the code. Therefore dictionary consultation during production activities is more sensible at the stage when the learner has completed the task and reads it critically for editing purposes.

A similar procedure may be followed with regard to production activities in L1: the student first writes the text and then consults a monolingual dictionary, synonym dictionary or thesaurus to improve or adapt the style where necessary and to enhance the expressive power of the work.

\section{Conclusion}

Dictionaries are no substitutes for teachers or textbooks: I certainly do not know of any person who has learnt a new language solely by using a dictionary. It must nevertheless be admitted that the dictionary is an indispensable tool within the language teaching programme. Moulin (Béjoint and Moulin 1987: 113) says in this regard:

"dictionary consultation, provided it is integrated within the whole language learning approach, remains nevertheless the safest way of making sure that the writer at least gets his word senses right. It is only when the writer reaches the level of the sentence or paragraph and encounters complex syntactic, stylistic or pragmatic problems that he comes up against the limitations of the dictionary. Those considerations cannot be taken as an excuse to skip those stages of the writing process where dictionaries, when used discriminatingly, prove to be such informative and reliable guides."

It is therefore essential that dictionary-using skills be taught according to a principled strategy and incorporated into language learning programmes. 
Moreover, students should be made aware of the problem-solving potential of dictionaries at an early age, in order to ensure bonding which will lead to a lifelong partnership.

\section{References}

Beattie, N. 1973. Teaching Dictionary Use. Modern Languages 54(4): 161-168.

Bejoint, H. and Moulin, A. 1987. The Place of the Dictionary in an EFL-programme. Cowie, A.P. (Ed.). 1987: 97-114.

Béjoint, H. 1989. The Teaching of Dictionary Use: Present State and Future Tasks. F.j Hausmann, O. Reichmann, H.E. Wiegand and L. Zgusta (Eds.). 1989: 208-215.

Blok, H. 1994. Het Woordenboek Gebruiken: Een Klein Kunstje? De Praktijk van het Basisonderwijs. Levende Talen 490: 276-279.

Bogaards, P. 1994. Leerwoordenboeken in het Talenonderwijs. Levende Talen 490: 264-269.

Cowie, A.P. (Ed.). 1987. The Dictionary and the Language Learner. Papers from the EURALEX Seminar at the University of Leeds, 1-3 April 1985. Lexicographica: Series Maior 17. Tübingen: Niemeyer.

Hannay, M. 1994. Het Handwoordenboek en de Gebruiker. Levende Talen 490: 254-258.

Hartmann, R.R.K 1987. Four Perspectives on Dictionary Use: A Critical Review of Research Methods. Cowie, A.P. (Ed.). 1987: 11-28.

Hartmann, R.R.K 1989. Sociology of the Dictionary-user: Hypotheses and Empirical Studies. Hausmann, F.J., O. Reichmann, H.E. Wiegand and L. Zgusta (Eds.). 1989: 102-111.

Hausmann F.J., O. Reichmann, H.E. Wiegand and L. Zgusta (Eds.). 1989. Wörterbücher / Dictionaries / Dictionnaires. Berlin: De Gruyter.

Herbst, T. and G. Stein. 1987. Dictionary-using Skills: A Plea for a New Orientation in Language Teaching. Cowie, A.P. (Ed.). 1987: 115-127.

Houtman, $\mathrm{K}$ and G. Wouters. 1994. 'Een boek waar alles in staat!' Gesprek met leerlingen over woordenboeken en een proef op de som. Levende Talen 490: 306-310.

Kipfer, B.A. 1984. Workbook on Lexicography. Exeter Litguistic Studies 8. Exeter: University of Exeter.

Kipfer, B.A. 1987. Dictionaries and the Intermediate student: Communicative Needs and the Development of User Reference Skills. Cowie, A.P. (Ed.). 1987: 44-54.

Lewis, R. and M. Pugmire. 1980. How to use your Dictionary. Cambridge: National Extension College.

Lombard, F.J. 1994. Lexicographer, Lingu ist and Dictionary User: An Uneasy Triangle? Lexikos 4 (AFRILEX-series 4:1994): 204-214.

Magay, T. and Zigany, J. (Eds.). 1990. Budalex '88 Proceedings. Papers from the 3rd International EURALEX Congress, Budapest 4-9 September 1988. Budapest: Akadémiai Kiadó.

Olijkan, E. 19941. Oefening in woordenboekgebruik in leergangen Nederlands, Engels, Frans en Duits voor de basisvorming. Levende Talen 490: 280-287.

Olijkan, E. 19942. Woordjes moet je snappen! Een discussie over het gebruik van woordenboeken in de klas. Levende Talen 490: 288-293.

Olijkan, E. and G. Wouters. 1994. Woordenboeken in de praktijk. Levende Talen 490: 252-253. 
Scholfield, P. 1982. Using the English Dictionary for Comprehension. Tesol Quarterly 16(2): 185. 194.

Snell-Homby, M. 1987. Towards a Leamer's Bilingual Dictionary. Cowie, A.P. (Ed.). 1987: 159. 170.

Stein, G. 1990. From the Bilingual to the Monolingual Dictionary. Magay, T. and Zigany, J. (Eds.). 1990: 401-407.

Underhill, A. 1980. Use your Dichionary. Oxford: Oxford University Press.

Whitcut, J. 1979. Learning with LDOCE. London: Longman. 